\title{
Hippocampal volume reduction after chemotherapy assessed by brain MRI: a cause of chemobrain in cancer patients
}

\author{
Kemoterapi sonrası hipokampüs hacmindeki azalmanın beyin MRG ile \\ değerlendirilmesi:kanser hastalarında kemobeyinin bir sebebi \\ Duygu Herek*, Gamze Gököz Doğu**,Mehmet Bülent Özdemir***,Burcu Yapar Taşköylü**, \\ Umut Çakıroğlu ${ }^{* *}$, Yurdaer Doğu****,Arzu Yaren ${ }^{* *}$ \\ *Pamukkale Üniversitesi, Tıp Fakültesi,Radyoloji ABD,Denizli \\ **Pamukkale Üniversitesi,Tıp Fakültesi,Tıbbi Onkoloji BD,Denizli \\ ***Pamukkale Üniversitesi, Tıp Fakültesi, Anatomi ABD,Denizli \\ ****Tekden Hastanesi,Beyin Cerrahisi Kliniği,Denizli
}

\begin{abstract}
Purpose:Cancer treatment (chemotherapy) affects various neural parts of the brain which results in cognitive impairments as problems in working memory, concentration, speed of processing and responding, and speech. This condition is called "chemobrain". The aim of this study is to establish whether any change exists in the volume of certain brain parts before and after chemotherapy that might play a role in chemobrain by means of magnetic resonance imaging (MRI).

Materials and methods: Eleven patients with various cancers underwent cranial MRI before and after chemotherapy. 3-dimensional reconstruction from coronal 2 dimensional images were obtained by SURFDriver program. Volume calculations of cerebrum, cerebellum, ventricles, right and left hippocampus were done by Cavalieri method.

Results:According to measurements there was a statistically significant difference only in the volumes of right and left hippocampus before and after chemotherapy $(p<0.05)$. The volumes of the hippocampus on both sides decreased after chemotherapy.

Conclusion:This study revealed significant volume changes in the hippocampus of cancer patients after chemotherapy. We suggest that this volume reduction in hippocampal regions might be the explanation of chemobrain seen in cancer patient during and after chemotherapy.
\end{abstract}

Pam Med J 2017;10(3):222-226

Keywords:Cognitive impairment, neoplasms, drug therapy, magnetic resonance imaging.

Özet

Amaç:Kanser tedavisi (kemoterapi) beyinin çeşitli nöral parçalarını etkileyerek hafıza, konsantrasyon, işleme ve karşılık verme hızı ve konuşma gibi alanlarda bilişsel bozukluklara neden olur. Bu duruma "kemobeyin" adı verilir. Bu çalışmanın amacı manyetik rezonans görüntüleme (MRG) aracılığıyla kemoterapi öncesi ve sonrası bazı beyin kısımlarında kemobeyin oluşmasına neden olabilecek herhangi bir hacim değişikliği olup olmadığını ortaya koymaktır.

Gereç ve yöntem:Farklı kanser tanıları olan 11 hastaya kemoterapi öncesi ve sonrası kraniyal MRG tetkiki yapıldı. Koronal 2-boyutlu görüntülerden SURFDriver programı kullanılarak 3-boyutlu rekonstrüksiyonlar elde edildi. Serebrum, serebellum, ventriküller, sağ ve sol hipokampüsün hacim ölçümleri Cavalieri yöntemi kullanılarak elde edildi.

Bulgular:Ölçümler sonucunda kemoterapi öncesi ve sonrası sadece hipokampüs hacimlerinde anlamlı farklılık vardı $(p<0.05)$. Her iki tarafta da hipokampüs hacimlerinde kemoterapi sonrası azalma görüldü

Sonuç:Bu çalışma kemoterapi sonrası kanser hastalarının hipokampüs bölgelerinde anlamlı hacim değişikliği olduğunu ortaya koymaktadır. Kemoterapi sırasında ve sonrasında kanser hastalarında görülen kemobeyinin nedeninin hipokampüs bölgelerindeki bu hacimsel azalmaya bağlı olduğunu düşünmekteyiz.

Pam Tıp Derg 2017;10(3):222-226

Anahtar sözcükler:Bilişsel bozukluk, neoplaziler, ilaç tedavisi, manyetik rezonans görüntüleme.

Duygu Herek

Yazışma Adresi:Pamukkale Üniversitesi,Tıp Fakültesi,Radyoloji ABD,Denizli

e-mail:dtherek@yahoo.com 


\section{Introduction}

Cognitive disorders including problems in working memory, concentration, speed of processing and responding, and speech are reported to be the adverse effects of cancer therapy [1-3]. Chemotherapy-induced cognitive dysfunction which is seen during or following cancer treatment is called "chemobrain" or "chemofog" [3-5]. Physiopathology of chemotherapy-induced cognitive impairment has been a challenge because chemotherapy itself causes fatigue and cancer treatment also has side effects as anxiety, depression, mood changes affecting cognitive functions of the person [3]. It is reported that some experimental studies demonstrated the cause of chemobrain as fluctuations in the circulating proinflammatory cytokines [1]. Some studies reported that level of cognitive disorders correlate with the dosage of adjuvant chemotherapy. As the dose increased cognitive dysfunction levels increased [4]. Monje and Dietrich [6] reported that cancer treatment disrupts the proliferation of healthy cells, such as those that give rise to new neurons in the adult hippocampus. Tasks that depend on hippocampus are affected more by the treatment [5]. It is mostly reported to end after the treatment ends.

In this study we tried to establish possible volume changes in different parts of the brain as cerebrum, cerebellum, ventricles, right and left hippocampus by means of magnetic resonance imaging (MRI) in patients who underwent cancer treatment. Magnetic resonance imaging was done before the treatment and control MRIs were taken after 6 months of drug treatments.

\section{Materials and methods}

\section{Study population, scanning and evaluation}

This study was approved by the local ethics committee (60116787/020/27525). Written informed consent was obtained from all patients included in the study. From August 2014 to January 2016 thirty-six patients with new cancer diagnosis were enrolled in the study. Twenty patients had breast cancer, 3 had pancreas cancer, 4 had ovarian carcinoma, 6 had lung cancer and 3 had gastric cancer. Eleven of the 36 patients underwent cerebral MRI, of the remaining 25 patients 14 died because of progressive disease and 11 were lost to followup MRI. Eleven patients who underwent MRI before and 6 months after chemotherapy were included in the study. Eight of 11 patients had breast cancer, 1 had ovarian cancer, 1 had lung cancer and 1 had pancreas cancer. Nine of them were female ( $82 \%)$ and 2 were male (18\%). Age range between $40-76$ years; mean $63 \pm 11$.

All MRI examinations were performed with a 1.5 Tesla $(T)$ MRI system (Ingenia; Philips Medical Systems, Best, The Netherlands) with a 16-channel head coil and high performance gradient (maximum gradient, $45 \mathrm{mT} / \mathrm{m}$; maximum slew rate, $200 \mathrm{~T} / \mathrm{m} / \mathrm{s}$ ). Coronal 2 dimensional (2D) T2-weighted turbo spin echo, echo planar imaging, sensitivity encoding (T2 -TSE EPI SENSE) (TR, $6000 \mathrm{~ms}$; TE, 100 $\mathrm{ms}$; number of excitations (NEX), 1 or 2; slice thickness, $4 \mathrm{~mm}$; flip angle, $90^{\circ}$ ) images were obtained for cerebral volume measurements. 3-dimensional (3D) reconstruction of the images was done by SURFDriver program [7]. Volume of the cerebrum, ventricles, cerebellum, right hippocampus and left hippocampus before and after chemotherapy were calculated from the images by using Cavalieri method.

\section{Statistical analysis}

Quantitative data were summarized as means and standard deviations and the changes in volumes of cerebrum, cerebellum, ventricles, right and left hippocampus before and after chemotherapy were compared by using Wilcoxon signed rank test. A $p$ value of 0.05 or less was defined as statistically significant. Calculations were performed on commercially available statistical software (SPSS version 21.0; IBM Corporation, Armonk, NY).

\section{Results}

Mean volumes of cerebrum, cerebellum, ventricles, right and left hippocampus were given on table 1. According to the measurements although there was no statistically significant change in the volumes of cerebrum, ventricles and cerebellum $(p>0.05)$, there was a statistically significant difference in the volume measurements of right and left hippocampus before and after chemotherapy $(p=0.003)$ (Figure 1).

\section{Discussion}

This study revealed a significant reduction in the hippocampal volume of cancer patients on both sides who had undergone chemotherapy and thus we assume that chemobrain might result from hippocampal volume changes in these patients.

Hippocampus is the part of limbic system that is involved in the storage of long term memory and knowledge of experiences. It stores memories and it is also able to recall 


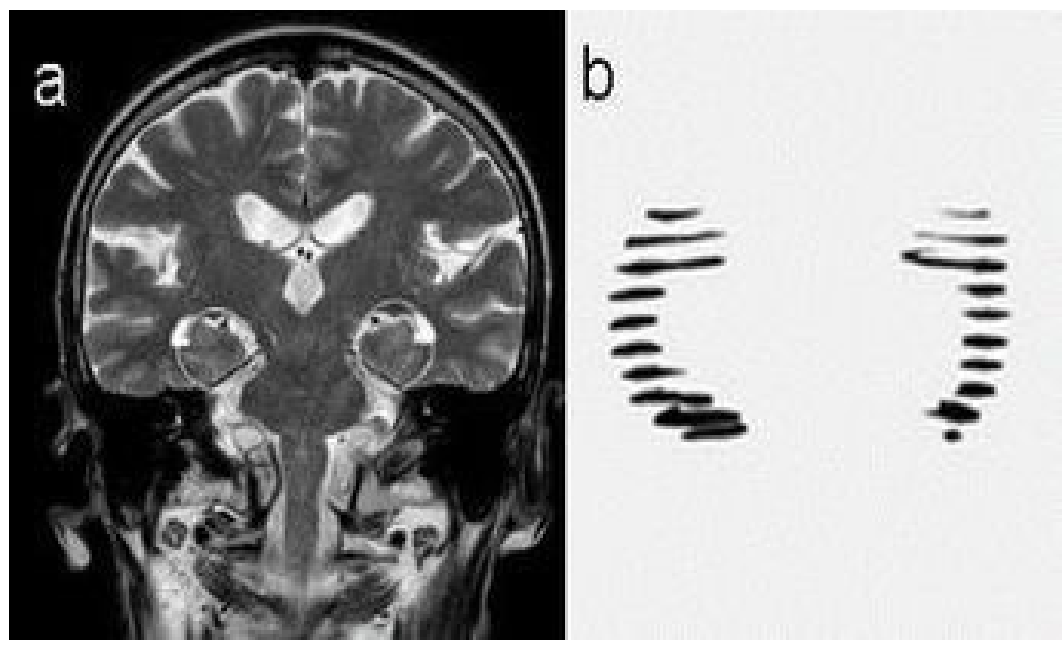

Figure 1.Coronal T2 weighted TSE MRI (a) of a 73- year-old patient with breast cancer is seen on the left. Hippocampal regions are shown in white circles. On the right (b) reconstruction of hippocampal regions by $3 \mathrm{D}$ reconstruction program is seen

Table 1. Mean values of the volumes of different brain parts before and 6 months after chemotherapy calculated using coronal MRI

\begin{tabular}{cccc}
\hline Brain parts & $\begin{array}{c}\text { Mean volume before } \\
\text { chemotherapy }\left(\mathbf{m m}^{\mathbf{3}}\right)\end{array}$ & $\begin{array}{c}\text { Mean volume } \mathbf{6} \text { months } \\
\text { after chemotherapy }\left(\mathbf{m m}^{\mathbf{3}}\right)\end{array}$ & P value \\
\hline Cerebrum & $912827 \pm 118517$ & $899576 \pm 103652$ & 0.13 \\
Cerebellum & $8728 \pm 1153$ & $8507 \pm 1078$ & 0.18 \\
Ventricles & $8507 \pm 1108$ & $8393 \pm 1029$ & 0.36 \\
Right hippocampus & $4306 \pm 366$ & $2978 \pm 345$ & 0.003 \\
Left hippocampus & $4192 \pm 284$ & $2885 \pm 320$ & 0.003 \\
\hline
\end{tabular}

Data are given as mean \pm standard deviation

$\mathrm{mm}^{3}$ : cubic milimeter

them [8].In cancer patients several studies reported various cognitive impairments called chemobrain [4,9-11]. Chemobrain was mostly studied and proved in patients who received treatment for breast cancer [6,11-14]. In a study with 39 breast cancer patients a decline in concentration and memory in $28 \%$ of patients was shown [15]. Another study reported that $63 \%$ of cancer survivors reported problems with concentration and attention, $50 \%$ problems with memory, and $38 \%$ problems with abstract reasoning [16]. Bender et al [17] reported deteriorations in working memory in women who received chemotherapy. Most studies reported mixed cognitive pattern in neuropsychological testing most of which showed disorders in verbal learning, memory, attention and concentration [18]. It is believed to be caused by damage to neural progenitor population that is responsible for adult hippocampal neurogenesis [6].

Studies with imaging methods are limited on this specific issue and structural changes were shown by magnetic resonance imaging
(MRI) in various studies. Manual segmentation protocols, automated methods and voxel based morphometry techniques were the methods that are used to uncover tissue density or volume changes on MRI which might result from chemobrain effect [10]. In our study we calculated the volumes of different brain parts with SurfDriver program on thin slice MRI. Inagaki et al [19] reported significant volume differences by using voxel based morphometry technique in grey matter of right prefrontal cortex and parahippocampal gyrus and white matter in the bilateral middle frontal gyri, left para-hippocampal gyrus, left precuneus and right cingulate gyrus that played role in cognitive functions such as memory and attention. Another study in breast cancer patients reported grey matter volume reduction in a network called "default mode network" (DMN) of the brain which is composed of precuneus, posterior cingulate, medial frontal, middle temporal and lateral parietal regions and hippocampus [13]. Functional MRI studies established that DMN is more vulnerable to disease and effects of 
chemotherapy in breast cancer patients [13]. Our study also revealed hippocampal volume loss on MRI 6 months after cancer treatment.

Our sample was composed mostly of breast cancer patients $(72 \%)$ who had doxorubicin (adriamycin), cyclophosphamide and paclitaxel treatment. Our one patient with squamous cell lung cancer had cisplatin, carboplatin and paclitaxel, one patient with pancreas cancer had gemcitabine and one patient with ovarian cancer had carboplatin, paclitaxel and bevacizumab therapies. In a study conducted with breast cancer patients who received doxorubicin and cyclophosphamide therapy with or without paclitaxel were reported to show worse performance on memory testing compared with healthy controls [20]. Other study reported deterioration in verbal memory, processing and psychomotor speeds and executive function in patients who received cyclophosphamide, methotrexate and fluorouracil treatment for breast cancer [21]. Another study in breast cancer patients who were treated with fluorouracil, epirubicin, and cyclophosphamide or with cyclophosphamide, thiotepa, and carboplatin or with cyclophosphamide, methotrexate and fluorouracil, established cognitive impairment 2 years after completion of chemotherapy [22]. All these studies pointed out that chemobrain might be independent from the drug that has been used during chemotherapy. But some authors have noted that dosage of the cancer drugs is much more correlated with cognitive changes in patients $[10,18]$. Schagen et al [23] reported in their cross-sectional study with breast cancer patients that ones who received high dose cyclophosphamide, thiotepa, and carboplatin treatment performed worse in neuropsychological tests. In our study all patients had been given standard dose chemotherapy protocols according to their tumor type.

This study had some limitations. First of all, our sample size was small because of the loss to follow-up. Second, we couldn't perform any neuropsychological tests to patients to evaluate the possible cognitive deterioration. Third, we only calculated the volume changes in different brain parts but we couldn't do any functional MRI studies because of the technical shortcomings of our MRI scanner. Lastly, since we had a limited number of patients for different cancer types, we did not correlate the hippocampal volume changes with types of drugs that have been used during treatment. We suggest that this could be an issue of a further study that can be conducted in a large group of patients.
In conclusion, our study established a significant volume loss in hippocampus of the patients on both sides after 6 months of cancer treatment. This finding correlated with some reports about hippocampal damage in chemotherapy patients. So, we also think that chemobrain in cancer patients under treatment is a result of hippocampal volume loss. However, further study should be done in a larger size sample to verify our findings.

Conflicts of interest:The authors declare that they have no conflict of interest.

\section{References}

1. Cheung $\mathrm{YT}, \mathrm{Ng} \mathrm{T}$, Shwe $\mathrm{M}$ et al. Association of proinflammatory cytokines and chemotherapyassociated cognitive impairment in breast cancer patients: a multi-centered, prospective, cohort study. Ann Oncol 2015;26:1446-1451.

2. Patel SK, Hurria A, Mandelblatt JS. Chemobrain: is it time to initiate guidelines for assessment and management? Oncology (Williston Park) 2014;28:797804.

3. Holmes D. Trying to unravel the mysteries of chemobrain. Lancet Neurol 2013;12:533-534.

4. Boykoff N, Moieni M, Subramanian SK. Confronting chemobrain: an in-depth look at survivors' reports of impact on work, social networks, and health care response. J Cancer Surviv 2009;3:223-232.

5. Nokia MS, Anderson ML, Shors TJ. Chemotherapy disrupts learning, neurogenesis and theta activity in the adult brain. Eur J Neurosci 2012;36:3521-3530.

6. Monje M, Dietrich J. Cognitive side effects of cancer therapy demonstrate a functional role for adult neurogenesis. Behav Brain Res 2012;227:376-379.

7. SURFdriver. [Online]. Available at:http://www.surfdriver. com. Accessed March 3, 2016.

8. Rolls ET. Theory of hippocampal function in memory. Hippocampus 1996;6:601-620.

9. Selamat MH, Loh SY, Mackenzie L et al. Chemobrain experienced by breast cancer survivors: a metaethnography study investigating research and care implications. PLoS One 2014;9:e108002.

10. Moore HC. An overview of chemotherapy-related cognitive dysfunction, or 'chemobrain'. Oncology (Williston Park) 2014;28:797-804.

11. Scherling CS, Smith A. Opening up the window into "chemobrain": a neuroimaging review. Sensors (Basel) 2013;13:3169-3203.

12. Hede K. Chemobrain is real but may need new name. J Natl Cancer Inst 2008;100:162-163,169.

13. Kesler SR. Default mode network as a potential biomarker of chemotherapy-related brain injury. Neurobiol Aging 2014;35:11-19.

14. Cheung YT, Shwe M, Tan YP, Fan G, Ng R, Chan A. Cognitive changes in multiethnic Asian breast cancer patients: a focus group study. Ann Oncol 2012;23:25472552.

15. Schagen SB, van Dam FS, Muller MJ, Boogerd W, Lindeboom J, Bruning PF. Cognitive deficits after postoperative adjuvant chemotherapy for breast carcinoma. Cancer 1999;85:640-650. 
16. Jansen CE, Cooper BA, Dodd MJ, Miaskowski CA. A prospective longitudinal study of chemotherapyinduced cognitive changes in breast cancer patients. Support Care Cancer 2011;19:1647-1656.

17. Bender CM, Sereika SM, Berga SL,et al. Cognitive impairment associated with adjuvant therapy in breast cancer. Psychooncology 2006;15:422-430.

18. Dutta V. Psychostimulants for chemotherapy induced cognitive changes in cancer, Ockham's razor, anyone? J Cancer Res Ther 2012;8:326-329.

19. Inagaki M, Yoshikawa E, Matsuoka Y,et al. Smaller regional volumes of brain gray and white matter demonstrated in breast cancer survivors exposed to adjuvant chemotherapy. Cancer 2007;109:146-156.

20. Conroy SK, McDonald BC, Smith, DJ,et al. Alterations in brain structure and function in breast cancer survivors: effect of post-chemotherapy interval and relation to oxidative DNA damage. Breast Cancer Res Treat 2013;137:493-501.

21. Koppelmans V, Breteler MM, Boogerd W,et al. Neuropsychological performance in survivors of breast cancer more than 20 years after adjuvant chemotherapy. J Clin Oncol 2012;30:1080-1086.

22. Schagen SB, Muller MJ, Boogerd W, et al. Late effects of adjuvant chemotherapy on cognitive function: a follow-up study in breast cancer patients. Ann Oncol 2002;13:1387-1397.

23. Schagen SB, Muller MJ, Boogerd W, Millenbergh GJ, van Dam FS. Change in cognitive function after chemotherapy:a prospective longitudinal study in breast cancer patients. J Natl Cancer Inst 2006;98:1742-1745. 